\title{
Future enterprise types and strategies for agile manufacture
}

\author{
I. I)ean and A. S. Carrie \\ Department of Design, Manufacture and Engineering \\ Management \\ University of Strathclyde \\ 75 Montrose Street, Glasgow, GI IXJ, UK \\ Tel: +t+(0) 1+1548289+ Fax: +44 (0) 1+1 5520557 \\ E-mail:a.s.carrie@strath.ac.uk
}

\begin{abstract}
Changes in the global marketplace require manufacturers to consider becoming agile. This may require manufacturers moving away from mass production towards the manufacture of mass-customised virtual products. A strategy is needed by such manufacturers to become agile. The paper presents a very brief discussion of the issues associated with agility and comments on the five future enterprise types proposed by a recent Eureka study. The paper suggests that the Product Complexity/Market Uncertainty Grid provides a useful framework for discussing the issues surrounding the evolution of a business towards agile manufacturing and the related forms of manufacturing organisation. An cvolutionary path. by which a mass producer can become an agile. virtual product producer is presented. The Product Complexity/Market Uncertainty Grid also provides insight into several decision areas. The paper discusses the managerial implications of these decisions concerning the re-engineering of the production process. and the selection of supporting enterprise type, strategic business unit operations strategy. market penetration method and degree of control over business partners.
\end{abstract}

\section{Keywords}

Agile manufacturing. Product Complexity/Market Uncertainty Grid, Enterprise types. Re-engineering. 


\section{INTRODUCTION}

Manufacturers are moving away from mass production as the ideal form of production. Customers used to like keeping up with the Joneses now they want to be different from the Joneses (Felstead, 1993). Manufacturers now need to be agile in order to offer different products to different customers. Customers value these products as unique solutions to their problems.

Some products will still be best made by mass production. Profits will be low on these products compared to profits made from agile products. Manufacturers will need to become agile to have a comfortable life rather than surviving. Production processes will need to be re-engineered for agility.

\section{AGILITY}

A dichotomy is emerging where products will be made either by mass production or by agile manufacturing. In fact the choice between becoming a mass producer or an agile manufacturer may be the only trade-off left in manufacturing (New, 1996). Mass production achieves low unit costs by producing large quantities of uniform products whereas agile manufacturing is capable of low unit costs while producing far smaller quantities of high quality, highly customised products (Goldman and Nagel, 1993). An agile manufacture must be able to compete on quality, delivery, flexibility and price leadership simultaneously (Roth, 1996).

The agile manufacturer makes virtual products in batches of one close to the customer to reduce design and delivery time (Davidow and Malone, 1993). The virtual product is a product that is customised and produced instantaneously in response to customer demand (Davidow and Malone, 1993). Therefore, agile manufacturing favours smaller scale, modular production facilities, and cooperation between enterprises (Goldman and Nagel, 1993). Agile manufacturers stick to what they do well - their core competence - and form alliances with companies with different core competencies. Co-operative initiatives between firms, and co-operation among strategic business units of the same firm, are central to agile manufacturing (Goldman and Nagel, 1993).

Research into the implications of agility as part of the Eureka project EU 1005 by the Department for Trade and Industry, hereafter referred to as DTI, (1994) resulted in the identification of five new generic models of enterprise.

These are:

The Elastic Enterprise

The Flexible Enterprise

The Total Service Enterprise

The Technological Leader

The Virtual Enterprise 
The elastic enterprise is in fact the mass producer of the future using lean technologies to adapt to changes in volume and maintain consistent levels of efficiency, quality and cost. The flexible enterprise can produce a large diversity of products in relatively small quantities. The total service enterprise develops long term relationships with customers to co-design products with the customer. The technological leader creates, and is quick to market, new product and process ideas. The virtual enterprise can identify profitable niche markets and organise itself and its allies to quickly satisfy that market.

The flexible enterprise, total service enterprise, technological leader and virtual enterprise generic enterprise models have aspects of agility. The agile manufacturer has to be flexible producing many different products quickly in small batches, ideally batches of one. Total service must be given to the customer. The virtual product is co-designed and formed as a result of the long term relationship established with the customer. "An agile product is a platform for profitable upgrade components and enriching services over its entire lifetime, not an object sold for profit in a one time deal" (Goldman, et al., 1995). The agile manufacturer has to be the technological leader. Investment in research and development has to take place to keep supplying solutions to the customer. The agile manufacturer must be able to hire the core competencies of other manufacturers. The agile manufacturer is a mix of these pure models - a flexible, total service. technological leader with the ability to become a virtual enterprise. The agile manufacturer must have these aspects, in greater or lesser degrees, but it must have them in order to meet customers' needs.

\section{THE PRODUCT COMPLEXITY/MARKET UNCERTAINTY GRID}

This study by the DTI (1994) used the Product Complexity/Market Uncertainty Grid, developed by Puttick (1987), to identify different types of manufacturer who would be affected by the need to become agile. Puttick developed the Product Complexity/Market Uncertainty Grid as a model to help manufacturers recognise the management implications of the types of products they make. Identifying how complex the product is (high or low) and the level of market uncertainty it faces (again high or low) identifies a product's type. From this grid, a manufacturer can classify its product as commodity, consumer durable, jobbing product or super value good.

As technology advances what was once a complex product to make becomes a well-known and recognised industry standard becoming obsolete as new, more complex products become available. A market is uncertain when a manufacturer does not know what products a customer will seek from it.

Figure 1 shows the Product Complexity/Market Uncertainty Grid along with the choice of production strategy: agile or mass, and appropriate enterprise type. Once the product type is known the appropriate production strategy can be selected. 
Super value goods, jobbing products and consumer durables are all virtual products that will need to be made by agile manufacturers. Agile manufacturers seek partners, be they other strategic business units of the organisation or other companies, to share the risk when a market is uncertain. A complex product means that a manufacturer would have to know many production processes. Alternatively, it can, like agile manufacturers, have good links with suppliers who know their own production processes very well. Thus each sticks to the production processes they know well - their core competencies. Commodities will continue to be mass produced. Their market certainty and low product complexity means that there is low risk and production of the product is easy to master. Figure 1 also illustrates suggested enterprise types that should be adopted to make commodities, consumer durables, jobbing products and super value goods. These enterprise types are the integrated enterprise, fractal organisation, extended enterprise, and virtual organisation respectively.

\begin{tabular}{|c|c|c|}
\hline & Product $\mathrm{C}$ & \\
\hline & High & Low \\
\hline High & Super Value Goods & Jobbing Products \\
\hline & Agile Manufacturing & Agile Manufacturing \\
\hline & Virtual Organization & Extended Enterprise \\
\hline antity & & \\
\hline & Consumer Durables & Commodities \\
\hline & Agile Manufacturing & Mass Production \\
\hline Low & Fractal Organization & Integrated Enterprise \\
\hline
\end{tabular}

Figure 1 The product complexity / market uncertainty Grid

\subsection{Evolution}

Under intense global competition manufacturers increasingly seek to produce high value added products rather than goods competing on price. These primarily lie within the super value goods quadrant of the grid. Similarly, in the era of agile manufacturing, manufacturers may wish to move to produce super value goods. 
This is where the best profits will lie - producing true virtual products for customers. Customers will pay for products that are vital solutions to the customer's problem rather than a product that could, after a lot of time and effort by the customer, be used to solve the problem. The customer sees the manufacturer adding value and will pay for this. Some manufacturers may be happy making the level of profits they currently achieve by making commodities, consumer durables and jobbing products.

Over time the production processes and organisation of the manufacturer could be adapted to move from making commodity products to making agile products. It has been said that "in every commodity product there is a differentiated product waiting to get out" (Benson. 1997). There are several examples of this trend. For example. explosives for the quarrying industry used to be a bulk product manufactured at the maker's plant. Now it is common for the basic ingredients to be shipped by tanker to the customer's quarry where they are mixed in situ and charged for on a basis of the number of tons of quarried rock produced. A commodity product could have some optional extras added to it for each customer thus turning it into a consumer durable. Learning from this would then allow the manufacturer to offer jobbing products built especially for each customer from standard components. Again learning from this enables the manufacturer to design and make completely new products for each customer. Such products being super value goods. Thus the manufacturer evolves from a commodity producer to a producer of super value goods. This evolutionary path is shown in figure 2 as a dashed line.

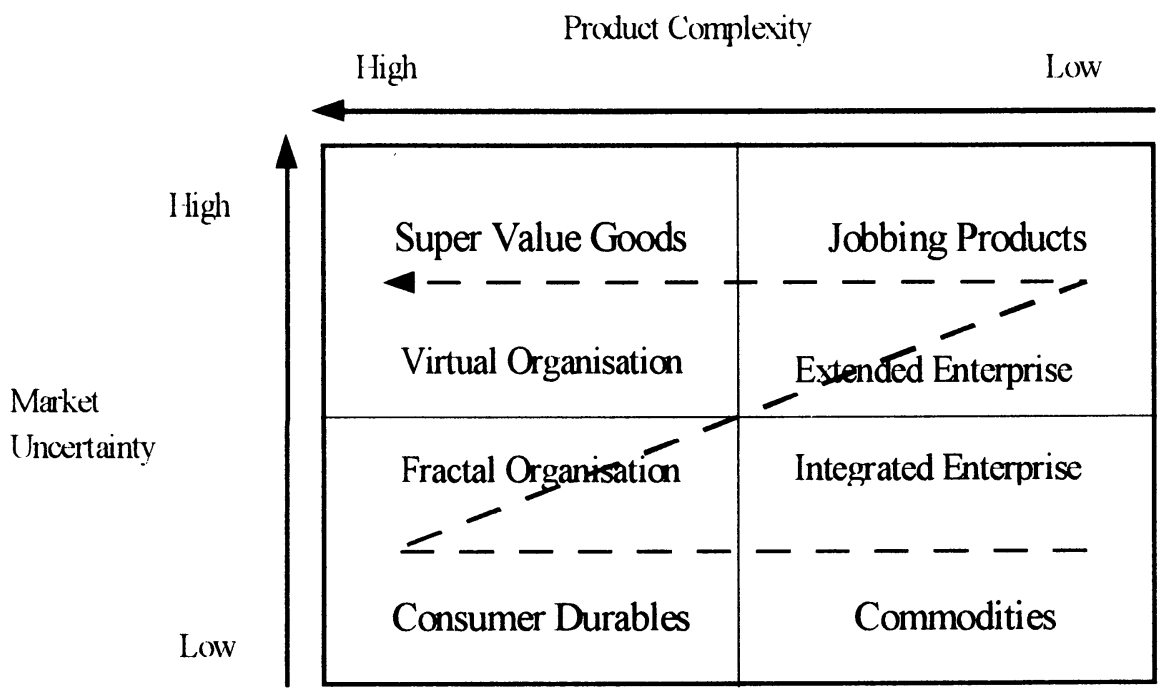

Figure 2 An evolutionary path to agility 
Although we have shown a single evolutionary path connecting the four types in sequence. in practice the path might be more like a tree, such as that depicting the evolution of ape-like species towards Homo sapiens. Thus some manufacturers may stop off at each stage with only a limited number evolving to the highest evolutionary state. In addition, other paths are conceivable, for example a company might evolve from commodity producer to job shop without going through the intermediate state of consumer durable manufacturer. However our purpose is to illustrate a concept rather than to present a single definitive model, and the remainder of the discussion is based upon the path depicted in figure 2 .

Adaptation of the production process and organisational form to give production units more autonomy will be needed by the manufacturer to move along the evolutionary path shown in figure 2 from producing commodities, through consumer durables and jobbing products to super value goods. Warnecke (1993) recognises this by arguing that all mass producers must make the step to agility by becoming a fractal organisation. Others prefer the term holon to fractal, in the context of holonic manufacture (van Leweren and Norrie, 1997), although the principles are much the same. Boynton, et al., (1993) argue that a manufacturer can become agile by first seeking continuous improvement then mass customising. The manufacturer will first need to become an extended enterprise (Barber, 1993). This will require a lot of effort (resources, people and money) and time. Once it is an extended enterprise it can make another push to become part of a virtual organisation.

\subsection{Commodities}

There will always be products whose standard form can readily solve the customer's problems. For these products price will continue to be the deciding factor. The manufacturer will need to keep costs down whilst being able to supply the customer immediately. Therefore logistics and production process technology become central core competencies for such a manufacturer. Costs are best controlled in an integrated enterprise, such as functionally based mass production favoured by many manufacturers in the 20th century. The manufacturer can readily keep an eye on all costs and take corrective action when needed. There will be profit in such products but it will be low compared to the profits made by manufacturers supplying virtual products.

\subsection{Consumer Durables}

All that the customer may seek in a virtual product to solve its problem is a standard commodity product that is adapted to its needs. In this case the customer regards value for money as being more important than fitness for purpose or timeliness. The production process will need to be just flexible enough to allow the product to be configured to the customer's needs. Different markets may 
require different adaptations. Thus a fractal organisation (Warnecke, 1993) will be necessary. This will involve establishing similar facilities in each market, each just flexible enough to make the adapted product. These production facilities are the transplants that many manufacturers use to make products tailored to local market requirements.

\subsection{Jobbing Products}

Assembling standard components together in a unique way for that customer can make virtual products. This unique way is a timely solution to the customer's problem. It is acceptable for the customer who cannot wait for a super value good to be developed. This requires an extended enterprise where the manufacturer purchases standard components from a network of key suppliers, each with an inimitable core competence. "The extended enterprise is rooted in the concept of outsourcing " (Barber, 1993). In the extended enterprise, co-operation takes place between firms carrying out different activities within the same general process. firms that operate at different points in the supply chain (Busby and Fan, 1993). This co-operation is based upon contract law, unlike the virtual corporation that is built more on trust.

The ability to mix and match these components is a core competence of the manufacturer. The extended enterprise requires a tight fit, and true synergy between trading partners (Barber, 1993). Thus the manufacturer will need to devote resources to knowledge. The key to this is knowledge transfer, the sharing of existing knowledge and the infrastructure to share new knowledge (Busby and Fan. 1993). The production process will need to be flexible to allow for these standard components to be combined in different ways.

An example of the extended enterprise is the franchised factory (Dean and Carric, 1996). A manufacturer can enter new markets by replicating its production process to a manufacturing company already supplying that market. Selling a franchise - the license to use the production process for an initial fee and royalties, does this. Each franchised factory becomes the supplier of the virtual product, on behalf of the extended enterprise, for a specified market. With production franchised out, in effect outsourced, the manufacturer, known as the franchiser, can concentrate on organising the supply of support services, such as research and development, marketing. accountancy: by itself or from other specialist firms. These manufacturing companies who have purchased the franchise are known as franchisees and pay for support services as part of their royalty payments to the franchiser.

Each franchisee is, in law, a separate business from the franchiser. However, the franchiser through a contract - the franchise agreement - controls the franchisees. The franchise agreement gives the franchiser considerable power over franchisees. Relationships can only be established with the permission of the franchiser. Franchisees are geographically dispersed so that franchisees cannot readily 
compare their experiences with the franchisers. The franchisees can only establish a franchise association with the permission of the franchisee. Thus the franchised factory cannot be a virtual organisation since relationships are built on contracts rather than trust. The franchise operations manual allows the transfer of knowledge initially between the franchiser and the franchisees. However, as franchisecs develop new product and process ideas, these product and process ideas are added to the franchise operations manual and shared with all partners in the franchise network.

\subsection{Super Value Goods}

These are true virtual products. These are usually one-off products that need a lot of research and development (R\&D) for their inception. Examples include defence products such as radar and aeroplanes both military and commercial. Knowledge acquisition to aid product creation is vital for the success of the project. This R\&D is too much for one firm to supply. Therefore a consortium is formed. Each member's core competence is pulled for the benefit of all. A virtual organisation is formed. Customers are seeking fitness for purpose so product design and development are necessary core competencies of the virtual organisation. Today a core competency in information technology is also needed to help the consortium communicate and manage design data.

\section{MANAGERIAL IMPLICATIONS}

The type of product a manufacturer wishes to make determines the method of manufacture. When the product's complexity and the certainty of a market for the product are identified the type of product can be derived using the Product Complexity/Market Uncertainty Grid. This grid allows the production strategy (agile manufacturing or mass production) to be elicited. Decisions can be taken that allow the:

Production process to be re-engineered,

Organisation to be formed,

Strategic business unit strategy identified.

Method of market penetration to be selected,

Amount of control over partners to be determined.

Table 1 shows these decisions derived from product type moving left to right. By knowing the product type, a manufacturer can select the appropriate production process and organisation to support production of that product. The strategy of the strategic business unit making that product and method of market penetration can also be identified. The degree of control over partners that the manufacturer will have can then be recognised. The following paragraphs explain 
the implications of these decisions for manufacturers making. or wishing to make, commodities, consumer durables, jobbing products or super value gocids.

Table 1 Decisions derived from product type

\begin{tabular}{|l|l|l|l|l|l|}
\hline Product type & $\begin{array}{l}\text { Process } \\
\text { Focus }\end{array}$ & $\begin{array}{l}\text { Enterprise } \\
\text { type }\end{array}$ & $\begin{array}{l}\text { Operations } \\
\text { strategy }\end{array}$ & $\begin{array}{l}\text { Market } \\
\text { penetration } \\
\text { method }\end{array}$ & $\begin{array}{l}\text { Degree of } \\
\text { control }\end{array}$ \\
\hline $\begin{array}{l}\text { Super value } \\
\text { goods }\end{array}$ & Project & $\begin{array}{l}\text { Virtual } \\
\text { organisation }\end{array}$ & $\begin{array}{l}\text { Technological } \\
\text { frontiersman } \\
\text { Cost } \\
\text { minimising } \\
\text { customiser }\end{array}$ & $\begin{array}{l}\text { Licensing } \\
\text { Joint } \\
\text { venture }\end{array}$ & Little \\
\hline $\begin{array}{l}\text { Jobbing } \\
\text { products }\end{array}$ & Facility & $\begin{array}{l}\text { Extended } \\
\text { enterprise }\end{array}$ & $\begin{array}{l}\text { Technological } \\
\text { serviceman }\end{array}$ & Franchising & More \\
\hline $\begin{array}{l}\text { Consumer } \\
\text { durables }\end{array}$ & Matter & $\begin{array}{l}\text { Fractal } \\
\text { organisation }\end{array}$ & $\begin{array}{l}\text { Technological } \\
\text { exploiter }\end{array}$ & $\begin{array}{l}\text { Wholly } \\
\text { owned } \\
\text { subsidiary } \\
\text { New branch }\end{array}$ & Substantial \\
\hline Commodities & $\begin{array}{l}\text { Transac- } \\
\text { tion }\end{array}$ & $\begin{array}{l}\text { Integrated } \\
\text { enterprise }\end{array}$ & $\begin{array}{l}\text { Cost } \\
\text { minimiser }\end{array}$ & Export & Complete \\
\hline
\end{tabular}

O'Brien (1995) argues that the type of process sought from a business process re-engineering exercise will result in different decisions having to be made. For example, the issues to resolve to move the production process from transactionbased to matter-based will be different from those issues that need to be resolved to move from a matter-based to a facility-based production process.

To make commodity products the mass producer will need to be an integrated enterprise. The production process will be transaction based (O'Brien, 1995) to minimise costs (Harris, et al., 1994). Concentrating production in one plant and exporting around the world can reduce costs. Management has complete control over this plant.

A manufacturer can take standard products and customise them by adding optional extras to make consumer durables. These are customisers according to Richardson. et al., (1984) and Harris, et al., (1994). The production process will need to be re-engineered from transaction based to matter based (O'Brien, 1995) with a fractal organisation structure adopted. This fractal structure will give the manufacturer substantial control over its subsidiaries. Such a manufacturer prefers to own subsidiaries if possible. Competitors who complement the product range or have technologies that can help the manufacturer are sought as targets to become wholly owned subsidiaries. In this respect the manufacturer is a technological exploiter (Richardson, et al., 1984 and Harris, et al., 1994). Alternatively, new branches are established in the new market. 
A manufacturer might treat the virtual product as a jobbing product where a new product is constructed from standard components. Such manufacturers will have mastered the production technology and know how to use it to combine components to meet customers needs. They are technological serviceman (Richardson. et al., 1984 and Harris, et al., 1994). To do this a manufacturer will establish an extended enterprise. The production process will be facility based (O'Brien, 1995). The production process will be adapted at each facility to make different products. Production facilities can readily be replicated through franchising giving the manufacturer more control.

A manufacturer seeking to make super value goods will be truly agile. Each super value good will be a project in its own right (O'Brien, 1995) causing a virtual organisation to be formed through joint venturing and licensing. Members of this virtual organisation will be technological frontiersmen or cost minimising customisers (Richardson, et al., 1984 and Harris, et al., 1994) due to their ability to exploit their investment in research and development. Such a manufacturer will want little control over partners in order to give them freedom to exploit their own expertise for the benefit of the virtual product.

\section{CONCLUSION}

In the recent past, when standard products sufficed, mass production was seen as the ideal. Now in the transition to agile manufacturing manufacturers have to choose their means of manufacture: mass or agile. This paper has presented the Product Complexity/Market Uncertainty Grid as a useful aid for this decision. This paper has shown that manufacturers may need to evolve their product and organise for agility by selecting an enterprise type based on the virtual organisation, extended enterprise (including the franchised factory) and the fractal organisation. From this, decisions on strategic business unit strategy, market penetration method and degree of control over partners can be made. This paper has demonstrated that with the help of Product Complexity/Market Uncertainty Grid a manufacturer can create a strategy to become agile. Manufacturers can use the fractal organisation and the franchised factory as stepping stones to move from mass production to agile manufacturing.

\section{REFERENCES}

Barber, N. F. (1993), Electronic Commerce: Toward the virtual corporation. EDI Forum. 6(4), pp. 18-22.

Benson, R. (1997), oral presentation to the Foresight Manufacturing, Production and Business Processes Panel, DTI, London. 11 May. 
Boynton, A. C., Victor, B. and Pine, B. J. (1993), New Competitive Strategies: Challenges to organisations and information technology. IBM Systems Journal. 32(1), pp. 40-64.

Busby. J. S. and Fan, I. S. (1993), The Extended Manufacturing Enterprise: Its nature and its needs. International Journal of Technologv Management, 8(35), pp. 294-308.

Davidow, W. H. and Malone, M. S. (1993), The Virtual Corporation. HarperBusiness, New York.

Dean. I. and Carrie, A. S. (1996), The Franchised Factory - A New Paradigm for Manufacturing. In: Proceedings of the European Operations Management Association Conference on Manufacturing Strategv: Operations strategv in a glohal context, (C. A. Voss (Ed.)). pp. 159-164.

Department for Trade and Industry. (1994), Factory for the Future: Synopsis of final report. Eureka project number EU 1005, HMSO, London.

Felstead. A. (1993), The Corporate Paradox: Power and control in the business franchise, Routledge, London.

Goldman. S. L. and. Nagel, R. N. (1993), Management, Technology and Agility: The emergence of a new era in manufacturing. International Journal of Technologv A.fanagement. 8(1-2), pp. 18-38.

Goldman. S. L., Nagel, R. N. and Preiss, K. (1995), Agile ('ompetitors and lirtual ()rganizations: Strategies for enriching the customer, Van Nostrand Reinhold, New York.

Harris. J., Grenhaigh. I. and Frizelle, G. (1994), CIM 2000: Manufacturing in the 21 st century. In: BPIC'S Annual Conference Proceedings.

New, C. (1996), Manufacturing and Corporate Strategy: Integration and focus polarisation. In: Proceedings of the European Operations Management Association ('onference on Manufacturing Strategv: Operations strategy in a global context. (C. A. Voss (Ed.)). pp. 477-482.

O'Brien. B. (1995). Decisions about Re-engineering: Briefings on issues and options. Chapman and Hall, London.

Puttick. J. (1987), Marketing Pull - Manufacturing Push: Springboard for competitive advantage. In: The Management of Manufacturing: The competitive edge. (R. P. Toone and D. Jackson (Ed.)), pp. 13-26. IFS (Publications) Ltd, London.

Richardson, P.R., Taylor, A.J. and Gordon, J.R.M. (1984), A Strategic Approach to Evaluating Performance. Interfaces, 15(6), pp. 15-27.

Roth, A. V. (1996), Competitive Progression Theory: Explanation and evidence.

In: Proceedings of the European Operations Management Association Conference on Manufacturing Strategy: Operations strategy in a global context. (C. A. Voss (Ed.)). pp. 563-568.

van Leweren. E.H. and Norrie, D. (1997), Holons and holarchies, Manufacturing Engineer. April. pp. 86-88.

Warnecke. H. J. (1993), The Fractal ('ompany. Springer-Verlag, Berlin. 


\section{BIOGRAPHIES}

PROFESSOR ALLAN S CARRIE Allan Carrie is Head of the Department of Design, Manufacture and Engineering Management at the University of Strathclyde. He also served a term as Head of Department from 1990 to 1992 . He is a Chartered Engineer, Fellow of the IEE and Senior Member of the Institute of Electrical and Electronics Engineers of USA. He is a Member of the Institute of Operations Management and is a Fellow of the Royal Society of Arts. He is also a member of the UK Technology Foresight Programme's Manufacturing Production and Business Processes Panel, Chairman of the Subgroup on the Electronics Industry and is currently a member of the EPSRC's College of Peers for Design and Integrated Production. He is a member of the Working Group on Computer-aided Production Management of the International Federation for Information Processing. He was Academic Leader on the Master of Technology Management Study Mission to Korea in 1997, Singapore in 1996 and USA in 1995.

On leaving school he joined Babcock and Wilcox as a Student Apprentice. After graduating in Mechanical Engineering, he completed practical training and served for a time as an Industrial Engineer. He left Babcock's to undertake postgraduate studies in Engineering Production at Birmingham University. He then worked as an Industrial Engineer with Northern Electric in Montreal, Canada. He joined the University of Strathclyde in 1968.

His research interests lie in the field of manufacturing systems and production management. He was awarded his $\mathrm{PhD}$ in 1976 for the development of an integrated package for plant layout and group technology. In the early 1980s he researched the application of personal computers to production control and simulation modelling of flexible manufacturing systems. Current contracts include projects on Performance Measurement Systems and on Manufacturing Franchising, both with funding from EPSRC and industrial collaborators. He recently completed a research project into Manufacturing Integration. He has worked extensively with industry, especially through Teaching Company Programmes. He is the author of a book entitled Simulation of Manufacturing Systems, has contributed to several other books and published over 100 papers. He has presented his work in several countries in Europe, North America and Asia.

IAN DEAN Ian Dean was a postgraduate student in the Department of Design, Manufacture and Engineering Management between 1994 and 1996. 